\title{
Modulation of Host Immunity by Beneficial Microbes
}

\author{
Christos Zamioudis ${ }^{1}$ and Corné M. J. Pieterse ${ }^{1,2}$ \\ ${ }^{1}$ Plant-Microbe Interactions, Department of Biology, Faculty of Science, Utrecht University, P.O. Box 800.56, 3508 TB \\ Utrecht, The Netherlands; ${ }^{2}$ Centre for BioSystems Genomics, P.O. Box 98, 6700 AB Wageningen, The Netherlands
}

Submitted 30 June 2011. Accepted 1 October 2011.

In nature, plants abundantly form beneficial associations with soilborne microbes that are important for plant survival and, as such, affect plant biodiversity and ecosystem functioning. Classical examples of symbiotic microbes are mycorrhizal fungi that aid in the uptake of water and minerals, and Rhizobium bacteria that fix atmospheric nitrogen for the plant. Several other types of beneficial soilborne microbes, such as plant-growth-promoting rhizobacteria and fungi with biological control activity, can stimulate plant growth by directly suppressing deleterious soilborne pathogens or by priming aboveground plant parts for enhanced defense against foliar pathogens or insect herbivores. The establishment of beneficial associations requires mutual recognition and substantial coordination of plant and microbial responses. A growing body of evidence suggests that beneficial microbes are initially recognized as potential invaders, after which an immune response is triggered, whereas, at later stages of the interaction, mutualists are able to shortcircuit plant defense responses to enable successful colonization of host roots. Here, we review our current understanding of how symbiotic and nonsymbiotic beneficial soil microbes modulate the plant immune system and discuss the role of local and systemic defense responses in establishing the delicate balance between the two partners.

Symbiotic and nonsymbiotic beneficial microbes in the rhizosphere.

In nature, plants are exploited by a plethora of microbial pathogens and insect herbivores that can cause severe diseases and pests. Beneficial relationships between plants and microorganisms are frequent in nature as well. They often occur in the rhizosphere and improve plant growth or help the plant to overcome biotic or abiotic stress. Each gram of soil contains billions of microbes. However, the microbial community on plant roots is very different from that in bulk soil, suggesting that plants are able to shape their microbiome (Badri and Vivanco 2009; Bais et al. 2004; Bisseling et al. 2009; Mendes et al. 2011). Well-known examples of beneficial microbes are mycorrhizal fungi that can form a symbiosis with approximately $80 \%$ of all terrestrial plant species (Harrison 2005; Van der Heijden et al. 1998). They acquire nutrients from the soil and deliver these to plant roots in return for photosynthates. Rhizobium bacteria form an intimate symbiotic relationship with leguminous plants, which leads to mutual recognition and

Corresponding author: C. M. J. Pieterse; Telephone: +31 30253 6887; Fax: +31 30253 2837; E-mail: C.M.J.Pieterse@uu.nl development of symbiotic structures in which the Rhizobium bacteria fix atmospheric nitrogen for the plant (Spaink 2000). Beneficial associations also include nonsymbiotic plantgrowth-promoting rhizobacteria (PGPR) and fungi (PGPF) of diverse genera, which can stimulate plant growth through degradation of soil pollutants, the production of phytostimulators, or by suppressing plant diseases or pests (De Vleesschauwer and Höfte 2009; Harman et al. 2004; Kloepper et al. 2004; Lugtenberg and Kamilova 2009; Pineda et al. 2010; Pozo and Azcon-Aguilar 2007; Shoresh et al. 2010; Van der Ent et al. 2009 b). The latter is often achieved through the elicitation of an induced systemic resistance (ISR) that is effective against a broad spectrum of foliar pathogens and even insect herbivores (Pineda et al. 2010; Van Loon et al. 1998; Van Wees et al. 2008). The establishment of beneficial associations requires mutual recognition and substantial coordination of plant and microbial responses. Rhizobial and mycorrhizal symbioses share a common symbiosis signaling (Sym) pathway which is activated in plant cells upon perception of the rhizobial nodulation (Nod) and mycorrhizal Myc factors, respectively (Bonfante and Genre 2010; Maillet et al. 2011; Oldroyd and Downie 2008; Oldroyd et al. 2009). Interestingly, it appears that certain signaling components of the Sym pathway may also be activated by nonsymbiotic beneficial microbes, such as PGPR, suggesting that plant signaling pathways triggered by different beneficial microbes are partly converged (Sanchez et al. 2005).

Immune signaling in the rhizosphere.

Both symbiotic and nonsymbiotic beneficial microbes are initially recognized as alien organisms. Hence, active interference with the plant immune system is fundamental for the establishment of intimate mutualistic relationships. Immune signaling in plants is initiated upon receptor-mediated perception of non-self molecules that are often conserved among different classes of microbes, both pathogenic and beneficial. These molecules are called microbe-associated molecular patterns (MAMPs), and MAMP-induced defense responses mounted in host plants are collectively referred to as MAMP-triggered immunity (MTI) (Boller and Felix 2009; Jones and Dangl 2006). Despite the fact that innate immune signaling in leaves has been extensively studied over the past years, very little is known about MTI in roots, where the majority of the plant-beneficial microbes reside. Only recently, Millet and associates (2010) demonstrated that Arabidopsis roots respond to different MAMPs in a tissue-specific manner and that MAMP-triggered immune signaling in the roots is very similar to that observed in the leaves. To establish a mutualistic interaction with the plant, beneficial microbes need to cope with host immune responses that are triggered locally in the roots upon MAMP perception. In this review, we focus on the strategies that sym- 
biotic and nonsymbiotic beneficial microbes evolved to reduce stimulation of host immune responses and actively suppress MTI.

\section{Modulation of host immunity in the legume-rhizobia symbiosis.}

Rhizobia have evolved to reduce stimulation of the host's immune system. In order to evade detection by the host immune system, successful microbes evolved ways to minimize recognition of their MAMPs. Flagellin, the major structural protein of flagella, is one of the best-studied bacterial proteins that is recognized as a MAMP by the plant immune system (Boller and Felix 2009). In Arabidopsis, flagellin is perceived by the FLAGELLIN-SENSING 2 (FLS2) receptor, after which an intracellular signaling cascade is initiated, leading to the activation of a defense program against the invading bacteria. The immunogenic properties of flagellin reside in the highly conserved N-terminus of the molecule. Flg22, a synthetic 22amino-acid peptide that corresponds to the conserved N-terminus of flagellin, is a potent elicitor of defense responses in Arabidopsis and other plant species (Felix et al. 1999). Recently, Lopez-Gomez and associates (2011) demonstrated that flg22triggered defense responses in the roots of Lotus japonicus negatively influence nodulation by inhibiting rhizobial infections and delaying the nodule organogenesis. However, flagellins from the legume symbiont Sinorhizobium meliloti are exceptionally divergent in the otherwise conserved flagellin epitope, and neither the crude flagellin extracts nor the corresponding flg22 synthetic peptide are able to elicit defense responses (Felix et al. 1999). Likewise, the roots of L. japonicus, although well able to respond to flg22, do not respond to purified flagellin from Mesorhizobium loti, suggesting that LjFLS2 is unable to sense flagellin molecules from the symbiotic partner (Lopez-Gomez et al. 2011). Taken together, it is intriguing to speculate that immune selective pressure exerted by the putative FLS2 orthologs of the leguminous hosts forced the emergence of escape mutations within the active flagellin epitope, hence providing the microsymbionts with an evolutionary advantage of reducing stimulation of the host's immune system.

Rhizobia initially elicit an MTI response which is subsequently suppressed. Large-scale gene expression profiling studies of early nodulation stages in the model legumes L. japonicus and Medicago truncatula revealed a significant induction of defense- and stress-related genes, indicating that the leguminous hosts initially recognize their symbiotic partners as a potential threat (Fig. 1A). However, the same cluster of genes was found to be downregulated at later stages of root nodule formation (Fig. 1B), indicating that the microsymbionts have evolved to actively suppress host defense responses (El Yahyaoui et al. 2004; Kouchi et al. 2004; Lohar et al. 2006; Moreau et al. 2011). Maunoury and associates (2010) recently reported two waves of transcriptional reprogramming in $M$. truncatula involving repression of defense-related genes followed by the activation of a nodule-specific transcriptome. By using a collection of plant and bacterial mutants, the authors demonstrated that this transcriptome switch is dependent upon a molecular dialogue between both partners.

Extracellular polysaccharides suppress host defense responses. Several rhizobial MAMPs have been identified that play a role in immune suppression in leguminous hosts, including common structural components such as lipopolysaccharides (LPS) and exopolysaccharides (EPS) (Fig. 1B). LPS are structural components of the outer membrane of gramnegative animal- and plant-associated bacteria and potent activators of host immune responses (Zeidler et al. 2004). Purified LPS of $S$. meliloti bacteria was shown to provoke typical immune responses in cell cultures of the non-host tobacco. However, cell cultures of the host plant $M$. sativa only weakly responded to $S$. meliloti LPS (Albus et al. 2001). Surprisingly, simultaneous application of $S$. meliloti LPS and a yeast elicitor to alfalfa cells resulted in the suppression of the elicitor-induced
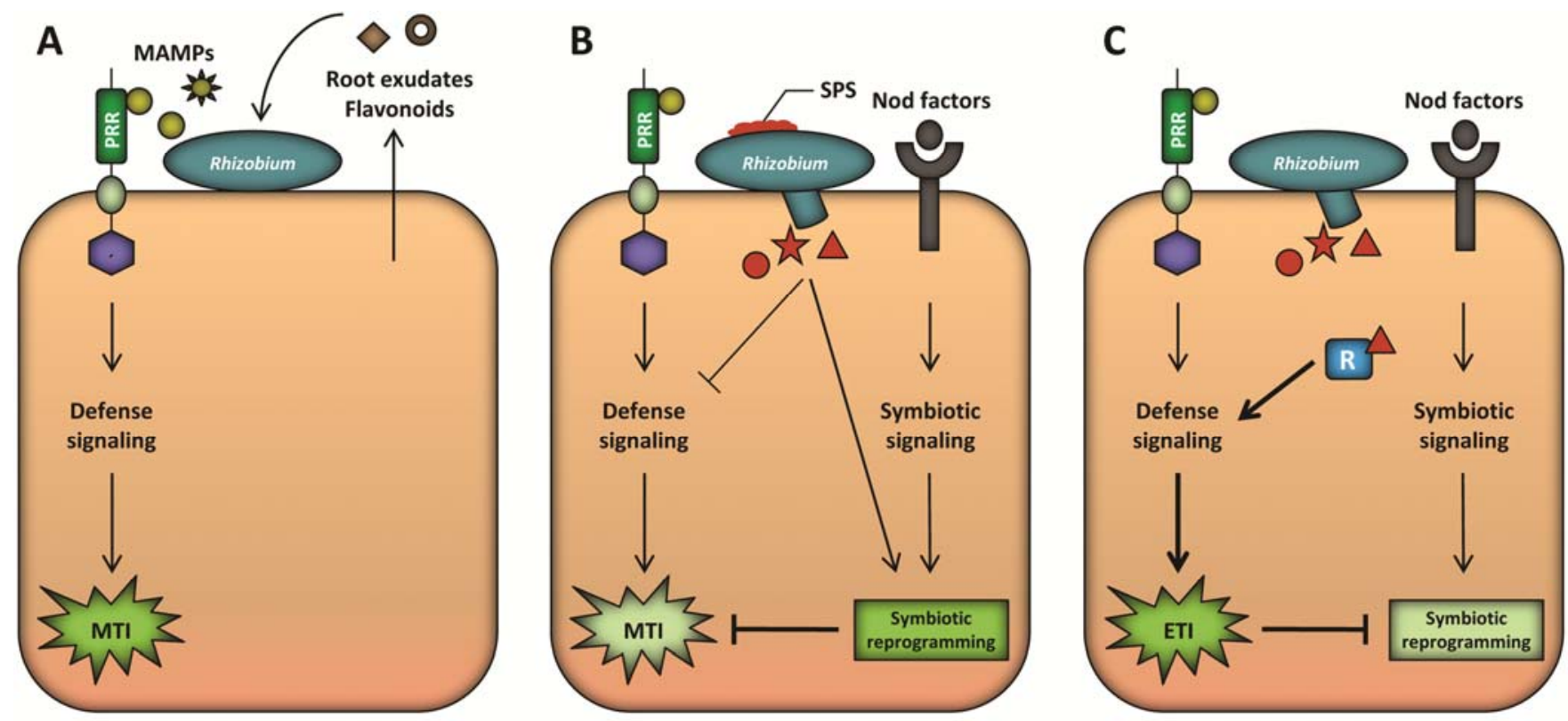

Fig. 1. Model for the modulation of host immunity in the Rhizobium-legume symbiosis. A, Root exudates recruit Rhizobium bacteria and secreted flavonoids prime the microsymbionts for the interaction. Host plants initially recognize rhizobia as potential invaders; pattern-recognition receptors (PRR) in the host perceive microbe-associated molecular patterns (MAMPs, yellow-colored shapes) and a signaling cascade is initiated that results in MAMP-triggered immunity (MTI). B, Surface polysaccharides (SPS) function early during the interaction, most likely as extracellular effectors to facilitate immune evasion. At later stages, the establishment of the symbiotic program in the plant cells, which is activated upon perception of the rhizobial nodulation (Nod) factors, counteracts the MTI with mechanisms yet to be defined. Rhizobial effectors that are secreted through the type III secretion system (brown-colored shapes) may assist in the suppression of the MTI response or act as symbiotic determinants. C, In the case that a host resistance (R) protein recognizes a cognate rhizobial effector, effector-triggered immunity (ETI) is activated that, in turn, terminates the interaction as incompatible. 
oxidative burst, indicating that LPS may act to suppress host defenses (Albus et al. 2001; Scheidle et al. 2005). Importantly, the ability of $S$. meliloti LPS to suppress elicitor-triggered defense responses is not only restricted to early events, such as the oxidative burst, but is also related to a global downregulation of the elicitor-induced transcriptional reprogramming (Tellstrom et al. 2007). The mechanism underlying the immunesuppressive effects of rhizobial LPS is yet to be identified. However, the fact that $S$. meliloti LPS suppresses host defenses in alfalfa hosts, whereas it typically triggers immune responses in non-host plants, suggests that legumes evolved a sophisticated LPS perception system able to differentially respond to pathogens and symbionts.

EPS are high molecular weight sugar polymers secreted by gram-negative and gram-positive bacteria with well-documented roles in bacterial physiology and pathogenicity. Acidic EPS are essential for rhizobia to establish symbiosis with host plants. Early studies have shown that failed infections by EPS-deficient rhizobial mutants are associated with the induction of defense responses such as callose deposition and production of antimicrobial compounds, indicating that EPS are involved in suppressing plant defense responses in the Rhizobium symbiosis (Niehaus et al. 1993). Microarray analysis further revealed that $M$. truncatula roots inoculated with the $S$. meliloti EPSdeficient mutant exoY more strongly induced the expression of defense-related genes than roots inoculated with the wild-type strain, indicating that EPS are required for efficient downregulation of host defense responses during early stages of infection (Jones et al. 2008). Aslam and associates (2008) demonstrated that the virulence function of EPS is based on its ability to chelate calcium anions, thereby blocking calcium influx into the cytosol, which is an essential step for the activation of a plethora of MAMP-trigged responses. Hence, calcium chelation may be an important mechanism underlying the immune-suppressive effects of rhizobial EPS.

Rhizobia suppress salicylic acid-dependent defense responses by utilizing the Nod signaling pathway. Salicylic acid (SA) is an important regulator of defense signaling against biotrophic and hemibiotrophic pathogens (Verhage et al. 2010; Vlot et al. 2009). SA signaling is predominantly transduced via the NPR1 protein which, upon its nuclear translocation, acts as transcriptional co-activator of SA-responsive genes (Dong 2004) and functions as a master regulator in the plant immune signaling network (Leon-Reyes et al. 2009; Pieterse et al. 2009). Rhizobia are mutualistic organisms and, therefore, it is likely that they are sensitive to SA-regulated defense responses. Indeed, several studies report negative effects of SA signaling on the rate and intensity of rhizobial infection and nodulation (Martinez-Abarca et al. 1998; Stacey et al. 2006; Van Spronsen et al. 2003). Interestingly, Peleg-Grossman and associates (2009) demonstrated that overexpression of NPRI in M. truncatula suppressed root hair deformation in response to $S$. meliloti, whereas RNAi-mediated reduction in the levels of NPR1 resulted in accelerated root hair curling. This is the first evidence that SA affects symbiosis through NPR1 and highlights the latter as a negative regulator in Rhizobium spp.-legume symbiosis.

On the other hand, rhizobia have evolved mechanisms to efficiently control the SA levels of host plants and establish successful infections. Martinez-Abarca and associates (1998) showed that alfalfa plants responded to incompatible Rhizobium strains by increasing the endogenous SA content whereas, in response to compatible strains, the SA level remained unchanged. Importantly, this same report also demonstrated that a Rhizobium mutant unable to synthesize Nod factors was also unable to reduce the endogenous SA levels, indicating that Nod-mediated
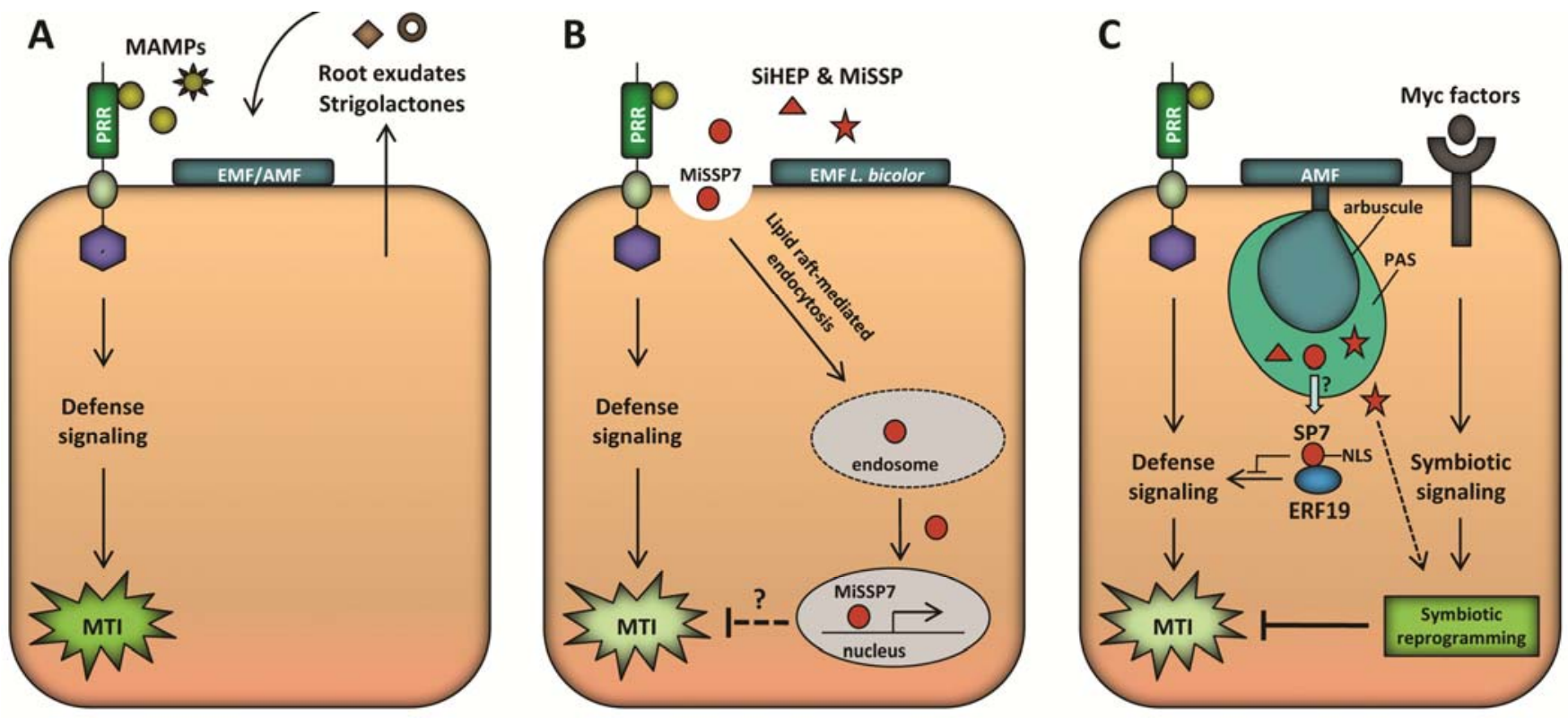

Fig. 2. Model for the modulation of host immunity in the ecto- and endomycorrhizal symbioses. A, Root exudates recruit symbiotic mycorrhizal fungi and prime them for the interaction. Host plants initially recognize ectomycorrhizal (EMF) and arbuscular mycorrhizal (AMF) fungi as potential invaders; patternrecognition receptors (PRR) in the host perceive microbe-associated molecular patterns (MAMPs, yellow-colored shapes) and a signaling cascade is initiated that results in MAMP-triggered immunity (MTI). B, The EMF Laccaria bicolor secretes proteins similar to the haustoria-expressed proteins of pathogenic basidiomycetes (SiHEP) and several cysteine-rich mycorrhiza-induced small secreted proteins (MiSSP) that may function as extra- or intracellular effectors to suppress host immune responses. The MiSSP7 effector is perceived by the plant cell through lipid-raft-mediated endocytosis and translocated into the nucleus, where it promotes auxin-related gene expression. It remains to be demonstrated whether upregulation of auxin signaling has a negative impact on plant defenses, as demonstrated for pathogenic interactions. C, In the AM symbiosis, the establishment of the symbiotic program in plant cells, which is activated upon perception of the mycorrhizal Myc factors, counteracts MTI with mechanisms yet to be defined. Molecules (brown-colored shapes) that are secreted in the apoplastic or periarbuscular space (PAS) may act as either apoplastic or cytoplasmic effectors to suppress the MTI response or promote the symbiotic program. The AMF Glomus intraradices secretes the SP7 effector which is translocated into the plant cytosol; a nuclear localization signal (NLS) targets SP7 to the nucleus, where it interacts with the defense-related transcription factor ERF19 to block the ERF19-mediated transcriptional program. 
signaling is required to suppress SA-triggered responses. Likewise, the expression of the $\beta$-glucanase MtBGLU1 gene, which is homologous to the pathogenesis-related (PR) $P R 2$ gene of tobacco, was found to be downregulated in the roots of M. truncatula $24 \mathrm{~h}$ after inoculation with $S$. meliloti but not after inoculation with a mutant that is unable to synthesize Nod factors (Mitra and Long 2004). Nod factors were found to be not only essential but also sufficient to downregulate MtBGLU1 expression. Moreover, the non-nodulating dmil mutant of $M$. truncatula was shown to be defective in MtBGLUl suppression, indicating that Nod-dependent MtBGLU1 suppression is part of the symbiotic signaling pathway (Mitra and Long 2004). Collectively, in addition to the essential role of Nod factors as signaling molecules in the nodulation process, evidence is accumulating pointing to a critical role of Nod signaling in overriding host defense responses triggered during rhizobial invasion (Fig. 1B). The molecular mechanisms by which Nod factors interfere with the host immune system are currently unknown. Nod factor perception at the epidermis leads to localized increases in levels of cytokinin and auxin in cortical cells (Oldroyd and Downie 2008). Thus, one possibility is that Nod factors locally affect the strength of the SA signaling pathway through hormonal crosstalk mechanisms, as demonstrated in diverse in plant-pathogen interactions (Pieterse et al. 2009).

Type III secreted rhizobial effectors as host-range specificity determinants. Plant- and animal-pathogenic bacteria possess a specific secretion machinery, called the type III secretion system (TTSS), to directly inject virulence effectors into the host cell (McCann and Guttman 2008). Many effectors are able to suppress MAMP-triggered immunity or manipulate the host's metabolic program to the pathogen's advantage (Boller and Felix 2009). Functional TTSS have been identified in several rhizobial species. In TTSS-harboring rhizobia, the type three secretion (tts) genes cluster together and are homologous to the hypersensitive response conserved ( $h r c)$ genes of pathogenic bacteria (Marie et al. 2001). Rhizobial proteins secreted through the TTSS are known as nodulation outer proteins (Nops) (Marie et al. 2001). Nops can be further grouped into proteins that are structurally associated with secretion appendages and effector proteins that are secreted into the host cell, where they are postulated to interfere with biological functions of the host. An important issue of whether rhizobial effectors are directly targeted into the host cell has been recently resolved. Translocation of rhizobial Nop proteins into the cytoplasm of plant cells has been experimentally confirmed for NopP of $S$. fredii and NopE1 and NopE2 of Bradyrhizobium japonicum (Schechter et al. 2010; Wenzel et al. 2010). NopL of the Rhizobium sp. strain NGR234 is the best-characterized effector to possess defense-suppressive functions. NopL acts as virulence factor when ectopically expressed in tobacco plants by downregulating virusinduced PR protein accumulation (Bartsev et al. 2004). Several Nop effectors show homology to effectors from plant and animal pathogens (Deakin and Broughton 2009), supporting the idea that the targets of bacterial effectors inside the host cells are conserved (Buttner and Bonas 2003).

In contrast to bacterial pathogens that depend on functional TTSS for pathogenesis, rhizobial effectors are not essential for the symbiosis because Rhizobium strains lacking a TTSS are still able to establish successful infections, form nodules, and fix nitrogen. Rhizobial type III effectors are likely to assist in the suppression of the MTI response, a role that is most likely superimposed on the dominant defense-suppressive functions of surface polysaccharides and Nod factors. Certain effectors may also act as symbiotic determinants, as demonstrated for the Y41O effector of Rhizobium sp. strain NGR234 (Yang et al. 2009) (Fig. 1B). Despite their elusive role in symbiosis, rhizobial type III effectors have long been considered to function as host range specificity determinants. Only recently, this level of specificity was found to be controlled by host Toll interleukin-1 receptor nucleotide-binding site leucine-rich repeat (LRR) resistance $(\mathrm{R})$ proteins that recognize cognate rhizobial effectors, resulting in effector-triggered immunity (ETI) (Fig. 1C) (Yang et al. 2010). The study of Yang and associates (2010) highlights a common recognition mechanism underlying symbiotic and pathogenic interactions and further suggests that rhizobia have evolved to suppress ETI in order to establish successful infections. Therefore, it is anticipated that, in the cocktail of effectors that a certain Rhizobium sp. injects into the host cytoplasm, certain effectors may possess avirulence activities while others have evolved to suppress the ETI response.

\section{Modulation of host immunity in mycorrhizal associations.}

Symbiotic mycorrhizal fungi reduce stimulation of the host's immune system. Other than through MAMPs, microbes can also be detected via damage-associated molecular patterns, which are endogenous plant-derived molecules that arise from damage or enzymatic degradation of cell walls, such as that caused by invading alien organisms. Interestingly, the genome of the ectomycorrhizal fungus (EMF) Laccaria bicolor lacks several gene families that encode for enzymes involved in the degradation of plant cell walls that could otherwise elicit immune responses (Martin et al. 2008). Likewise, the EMF Tuber melanosporum (black truffle) also carries a relatively small number of carbohydrate-cleaving enzymes (Martin et al. 2010). This particular genomic feature is also apparent in the genomes of the fungal pathogen Ustilago maydis (Kamper et al. 2006) and the oomycete Hyaloperonospora arabidopsidis (Baxter et al. 2010) and mirrors an evolutionary adaptation of symbiotic fungi and certain plant pathogens to a symbiotic and biotrophic lifestyle, respectively.

Mycorrhizal fungi initially elicit an MTI response, which is subsequently suppressed. Early studies regarding the interaction between plants and arbuscular mycorrhizal fungi (AMF) revealed that expression of defense- and stress-related genes is prominent during early stages of the interaction and subsequently declines as the symbiosis develops (Kapulnik et al. 1996). Most research based on large-scale transcriptional profiling in various symbiotic plant-mycorrhiza interactions revealed that defense-related gene expression in host plants follows similar expression patterns (Heller et al. 2008; Liu et al. 2003). Thus, the transcriptional response activated in roots upon mycorrhization may be similar to the two-wave transcriptional reprogramming reported for Rhizobium sp. symbiosis. Collectively, these data suggest that hosts initially treat symbiotic fungi as potential invaders and activate a defense program (Fig. 2A), which is then countered by the mycorrhizal symbionts (Fig. 2B and C).

Insights into the genome of mycorrhizal fungi: secretion of effector-like molecules. Sequencing of the genomes of the EMF Laccaria bicolor and T. melanosporum provided the first important evidence that symbiotic fungi may use strategies similar to those of pathogenic fungi to evade host immunity. In Laccaria bicolor, whole-genome sequence analysis combined with genome-scale expression profiling revealed candidate molecules that may act as effectors in modulating plant innate immunity, as demonstrated for effectors of several pathogenic fungi and oomycetes (Martin et al. 2008). Twelve predicted proteins of the symbiotic fungus share significant similarity with haustoria-expressed secreted proteins that are involved in pathogenesis of pathogenic basidiomycetes (Martin et al. 2008). In addition, the genome of Laccaria bicolor encodes a number of small secreted proteins (SSP), many of which are induced during the symbiotic interaction. Several cysteine-rich mycorrhiza-induced SSP (MiSSP) show significant similarity 
to cysteine-rich apoplastic effectors of pathogenic fungi (Martin et al. 2008), suggesting that they may function as extracellular or intracellular effector-type molecules to suppress defense signaling pathways. Recently, Plett and associates (2011) demonstrated that the effector MiSSP7 of Laccaria bicolor is perceived by the plant cell through lipid-raft-mediated endocytosis and is translocated into the nucleus, where it promotes auxin-related gene expression (Fig. 2B). Whether upregulation of auxin signaling has a negative impact on plant defenses, as demonstrated for pathogenic interactions (Kazan and Manners 2009), remains to be demonstrated. It should be noted that, in the T. melanosporum ectomycorrhizas, MiSSP are not induced (Martin et al. 2010), indicating that, in different symbiotic systems, different molecules may operate as effectors.

In contrast to the EMF, the genomes of the AMF are not assembled yet and, thus, predictions for putative effectors in the AM symbioses remain elusive. AMF, on the one hand, and certain biotrophic fungal and oomycete pathogens on the other hand, employ similar invasion strategies to infect their hosts (Paszkowski 2006). The transcriptional responses mounted in host plants in response to biotrophic pathogens and AMF significantly overlap, pointing to the existence of conserved molecules that execute similar functions (Paszkowski 2006). Therefore, it is anticipated that certain molecules secreted by the AMF in the apoplastic or periarbuscular space during the interaction with the host act as either apoplastic or cytoplasmic effectors in order to short-circuit the plant defense program. The SP7 effector of the AMF Glomus intraradices is the first endomycorrhizal effector described thus far to possess defense-suppressive activity (Kloppholz et al. 2011). SP7 expression is induced upon contact with the host roots and the secreted protein is translocated into the plant cytosol. A nuclear localization signal subsequently targets SP7 to the nucleus, where it interacts with the defense-related ethylene (ET)-responsive factor ERF19 to block the ERF19-mediated transcriptional program (Fig. 2C). The identification of the SP7 protein as a mycorrhizal effector that interferes with the ET signaling pathway is in line with recent data that highlight the importance of this hormone in MTI (Boutrot et al. 2010; Clay et al. 2009; Mersmann et al. 2010; Millet et al. 2010).

Mycorrhizal fungi suppress SA-mediated defense responses by utilizing the Myc signaling pathway. Similar to Rhizobium spp. symbiosis, SA signaling has been shown to negatively affect root mycorrhization by AMF (Blilou et al. 1999; Medina et al. 2003). On the other hand, strict regulation of the SA content is a prerequisite for efficient colonization. Recently, López-Ráez and associates (2010) demonstrated that the SA content and, accordingly, the expression of the SA-responsive gene PRla, was exclusively elevated in tomato roots colonized by the AMF $G$. mosseae but not $G$. intraradices, a fungus known to colonize tomato plants at higher rates. Likewise, SA only transiently accumulated during early stages of the interaction between pea and the AMF G. mosseae (Blilou et al. 1999). In the nonmycorrhizal P2 mutant of pea (Pisum sativum), the initial increase in the SA levels persisted, indicating that, like rhizobia, AMF modulate SA-mediated responses by utilizing the Myc signaling pathway. Interestingly, in the $M$. truncatula-Gigaspora margarita interaction, the activity of the $\mathrm{Ca}^{+2} /$ calmodulin kinase DMI3 is required to repress the expression of early induced defense-related genes (Siciliano et al. 2007), suggesting that perception of Myc factors also contributes to the repression of early MTI responses (Fig. 2C).

\section{Modulation of host immunity in nonsymbiotic beneficial interactions.}

PGPR may use phase variation to avoid stimulation of the host's immune system. Like rhizobia and mycorrhizal fungi, nonsymbiotic beneficial microbes such as PGPR, that often grow endophytically inside the roots, should also minimize stimulation of their host's immune system. Phenotypic variation or phase variation is an adaptive process by which bacteria can reversibly switch between colonies with different morphology (Davidson and Surette 2008). At the molecular level, phase variation is controlled by diverse genetic mechanisms, including site-specific DNA rearrangements and epigenetic modifications (Hallet 2001; Wisniewski-Dye and Vial 2008). Either of these mechanisms generates bacterial subpopulations within a clonal population that differentially express surface molecules (e.g., flagella or LPS) or express surface molecules with altered structure (Van der Woude and Baumler 2004). Phase variation provides bacteria with a significant advantage of adaptation to different environments and has been extensively documented in several studies as a mechanism that animal pathogens employ to escape immune detection (Kingsley and Baumler 2000). Phenotypic variation is also common among rhizosphere pseudomonads and has been reported as a conserved strategy that bacteria have evolved in order to increase their overall fitness in the rhizosphere (Van den Broek et al. 2005). Rhizosphere Pseudomonas bacteria may use antigen variation to reduce their antigenic potential and, therefore, minimize stimulation of the host's immune system. For instance, the PGPR Pseudomonas brassicacearum shows two distinct morphological variants designated as phase I and phase II (Achouak et al. 2004). Phase I cells are found on the basal parts of the root and produce significantly lower amounts of flagellin compared with phase II cells, which are predominantly found on secondary roots and root tips (Achouak et al. 2004). It is possible that, once colonization of new root niches is achieved, $P$. brassicacearum shifts into phase I cells in order to mask flagellin recognition by the host. Interestingly, $P$. aeruginosa was recently found to excrete an alkaline protease (AprA) that degrades flagellin monomers that serve as ligands for the immune receptors FLS2 in plants and TLR5 in mammals, thereby evading host immune activation in both plants and mammals (Bardoel et al. 2011). In P. brassicacearum, AprA was demonstrated to be expressed in phase I cells (Achouak et al. 2004), supporting the hypothesis that phase variation plays a role in immune evasion.

Nonsymbiotic microbes initially elicit an MTI response. Immune responses to elicitor molecules derived from PGPR are best characterized for selected ISR-inducing strains of fluorescent pseudomonads (Bakker et al. 2007; Van Wees et al. 2008). Cell wall preparations of various ISR-inducing rhizobacteria all triggered typical immune responses in tobacco suspension cells, including a burst of reactive oxygen species, extracellular medium alkalization, rapid elevation of cytoplasmic $\mathrm{Ca}^{+2}$, and defense-related gene expression (Van Loon et al. 2008). Furthermore, heat-killed $P$. fluorescens WCS417 bacteria were shown to activate the expression of MAMP-responsive reporters and trigger callose depositions in Arabidopsis roots (Millet et al. 2010). Recently, Jacobs and associates (2011) demonstrated that the PGPF Piriformospora indica is also recognized by the root immune system through its MAMPs. Thus, both PGPR and PGPF possess a pallet of MAMPs able to elicit MTI in the roots of host plants (Fig. 3A). On the other hand, evidence is accumulating that nonsymbiotic beneficial microbes actively suppress the defense responses that are initially mounted in roots upon MAMP perception (Fig. 3B and C).

Nonsymbiotic microbes utilize effector molecules to suppress MTI. Recently, Millet and associates (2010) provided evidence that the PGPR P. fluorescens WCS417 is able to suppress flagellin-triggered MTI responses in Arabidopsis roots via apoplastic secretion of one or more low molecular weight molecules (Fig. 3B). Bacterial determinants that have been 
demonstrated to be essential for rhizobial infections, such as LPS and EPS, may have similar functions in suppressing MTI during early stages of interaction between PGPR and host plants. Indeed, a $P$. fluorescens WCS417 mutant lacking the $O$ antigenic side chain of its outer membrane LPS was demonstrated to colonize tomato roots to a lesser extent than the wild-type strain (Duijff et al. 1997), suggesting a role for wildtype LPS in immune suppression. Presuming the importance of ET in MTI (Clay et al. 2009; Millet et al. 2010), another plausible scenario is that $P$. fluorescens-secreted molecules target ET-dependent defense processes. A wide range of PGPR have been shown to secrete the enzyme ACC deaminase, which degrades the ET precursor ACC, resulting in reduced ET production in the plant (Glick et al. 2007). Moreover, a significant reduction in the expression of genes Encoding ETrelated transcription factors has been reported for Arabidopsis roots colonized by PGPR $P$. fluorescens WCS417 and FPT9601-T5 (Verhagen et al. 2004; Wang et al. 2005), which supports the hypothesis that PGPR modulate host immune responses by interfering with the ET signaling pathway.

In the Piriformospora indica-Arabidopsis interaction, the beneficial fungus recruits the jasmonic acid (JA) signaling pathway to suppress both early- and late-activated defense responses (Fig. 3C). Also, suppression of the flg22-mediated MTI in the roots by the plant pathogen Pseudomonas syringae was demonstrated to depend on a functional JA signaling pathway (Millet et al. 2010). In both cases, suppression of MTI was mediated via the JA signaling components JAR1 and MYC2, suggesting that activation of the JA pathway may be a common strategy to affect host immunity in the roots.

Hormone-like compounds produced by PGPR may contribute to the suppression of the SA signaling pathway. Induction of SA-mediated responses have been demonstrated to reduce bacterial abundance in the plant rhizosphere (Doornbos et al. 2011; Kniskern et al. 2007). Also, colonization of Arabidopsis roots by the PGPF Piriformospora indica is affected by SA signaling (Jacobs et al. 2011). Many PGPR and PGPF are able to produce substantial amounts of phytohormone-like compounds, such as auxins and gibberellins (Lugtenberg and Kamilova 2009; Sirrenberg et al. 2007). Several phytohormones have been demonstrated to negatively cross-communicate with the SA signaling pathway and affect the outcome of the immune response (Pieterse et al. 2009; Verhage et al. 2010). Hence, it is tempting to speculate that nonsymbiotic microbes may produce phytohormones in order to attenuate the relative strength of the SA signaling via hormonal cross-talk mechanisms.

Type III secreted PGPR effectors: host-specificity determinants? The existence of a classical TTSS is not restricted only to pathogenic bacteria and rhizobia but also occurs in other nonpathogenic, root-associated bacteria. TTSS was first described for the PGPR P. fluorescens SBW25 (Rainey 1999) but other fluorescent pseudomonads are also equipped with a TTSS (Mavrodi et al. 2011; Mazurier et al. 2004; Preston et al. 2001; Rezzonico et al. 2004). In P. fluorescens SBW25, genes encoding for TTSS reside in a 20-kb tts cluster (named $r s c / r s p$ ) and several ORF in the cluster display a significant degree of similarity to the $h r c / h r p$ genes of pathogenic bacteria (Preston et al. 2001). P. fluorescens SBW25 is believed to secrete at least one effector and this is RopE of the AvrE family, a widely conserved family of effectors. There is also evidence for the existence of additional effectors, because ropE mutants are still able to trigger HR in Nicotiana clevelandii. P. fluorescens Q8r1-96 was recently reported to secrete the type III effectors RopAA of the HopAA1-1 family of effectors, RopM of the HopM1 family, and the unique RopB effector (Mavrodi
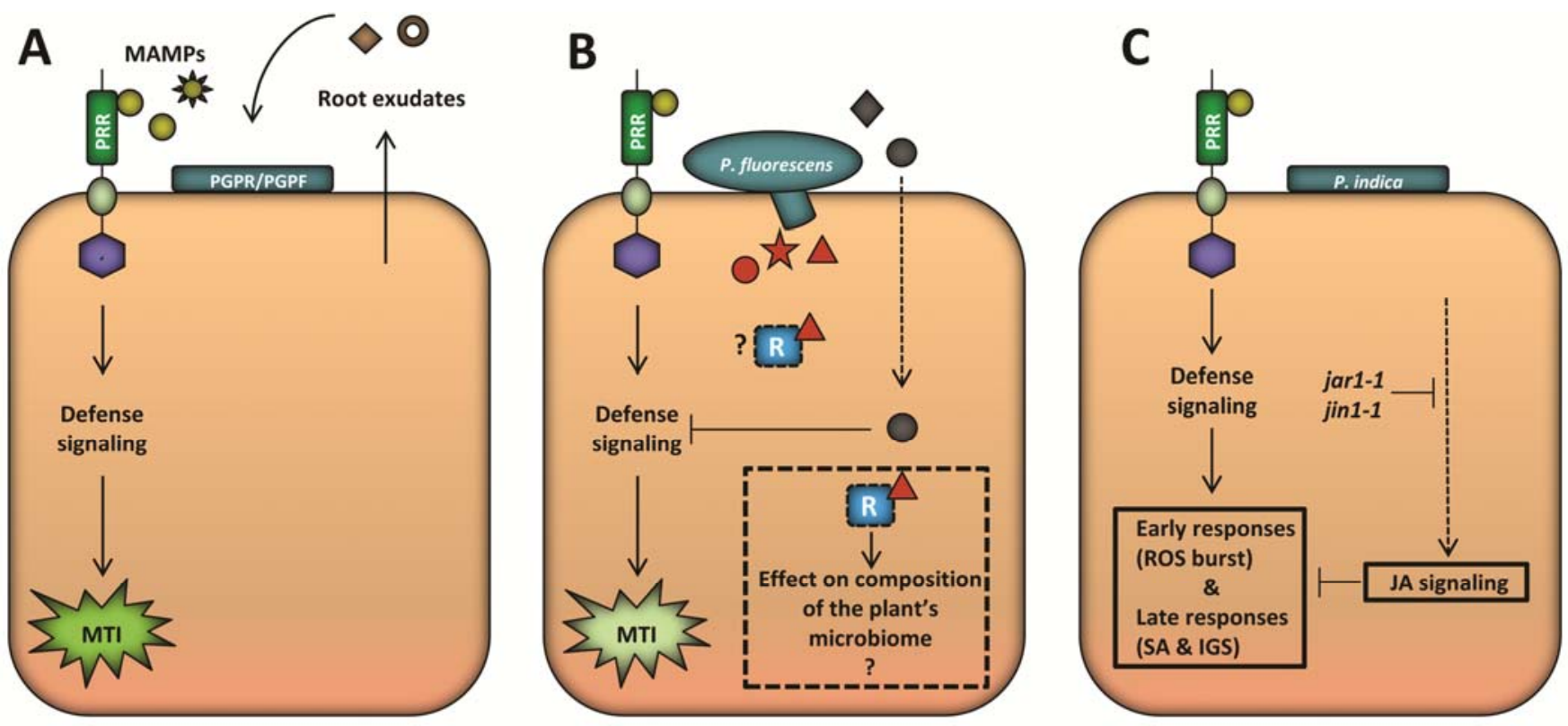

Fig. 3. Model for the modulation of host immunity during interactions with nonsymbiotic plant-growth-promoting rhizobacteria (PGPR) and fungi (PGPF) A, Root exudates recruit PGPR and PGPF and prime them for interaction. Host plants initially recognize PGPR and PGPF as potential invaders; patternrecognition receptors (PRR) in the host perceive microbe-associated molecular patterns (MAMPs, yellow-colored shapes) and a signaling cascade is initiated, resulting in MAMP-triggered immunity (MTI). B, The PGPR Pseudomonas fluorescens WCS417 suppresses the MTI response via apoplastic secretion of one or more thus-far-unidentified effector molecules (gray-colored shapes). Whether the secreted molecules act as apoplastic or cytoplasmic effectors and the mechanisms by which they interfere with the host immune system remain currently unknown. Effector molecules (brown-colored shapes) that are secreted via the type III secretion apparatus of $P$. fluorescens and other PGPR are likely to assist but seem not to be essential for MTI suppression. In analogy to root nodule symbiosis, certain type III effectors may be recognized by host resistance (R) proteins which, in turn, may impact the composition of the microbial community in the rhizosphere. C, The PGPF Piriformospora indica recruits the jasmonic acid (JA) signaling pathway to suppress both early (reactive oxygen species [ROS] production) and late (salicylic acid [SA]-mediated responses and indole glucosinolate [IGS] production) defense responses. This is mediated via the JA signaling components JAR1 and MYC2 (JIN1) because the JA-related mutants jar1-1 and jin1-1 of Arabidopsis are unable to suppress MTI. 
et al. 2011). Interestingly, all three type III effectors were found to be capable of suppressing typical innate immune responses when ectopically expressed in $N$. benthamiana (Mavrodi et al. 2011). Several mutations in components of the TTSS of $P$. fluorescens SBW25 have been shown to affect the competitive colonization capacity of the bacterium in the rhizosphere of sugar beet (Jackson et al. 2005). However, it is worth noticing that all of these mutants displayed altered in vitro growth compared with the wild-type strain, suggesting a more general role of the TTSS in the physiology of $P$. fluorescens SBW25 (Jackson et al. 2005). On the other hand, P. fluorescens Q8r1-96 mutants lacking functional TTSS are not altered in their rhizosphere competence (Mavrodi et al. 2011). Overall, the significance of type III secretion in PGPR remains far from clear. Effectors delivered via the TTSS of PGPR may either assist in the suppression of the MTI response or manipulate certain host's metabolic processes for their own benefit. Further research is needed to address whether $\mathrm{R}$ proteins in the host are evolved to recognize PGPR effectors and, thereby, may be instrumental in shaping the plant's microbiome in the rhizosphere (Fig. 3B). Earlier work already demonstrated that plant immune responses triggered by PGPR depends on the host-PGPR combination (Ton et al. 1999, 2002; Van Loon et al. 1998; Van Wees et al. 1997), suggesting a gene-for-genetype relationship between plants and mutualistic rhizobacteria.

\section{Local and systemic defense responses contribute to balancing the costs of mutualism.}

Despite their net fitness benefit, mutualistic interactions often also come with fitness costs. Therefore, host plants have evolved strategies to control the extent to which a mutualistic association develops. A considerable body of work implicates a role for induced plant defense responses in the control of these processes.

Local JA and ET signaling in the control of beneficial interactions. Plant oxylipins make up an important class of oxidized fatty acids commonly involved in pathogenic interactions as either antimicrobial agents or signaling molecules regulating plant defense responses (Wasternack 2007). The oxylipin JA and its derivatives (collectively called jasmonates) play an important role in the regulation of plant-beneficial microbe interactions (Van der Ent et al. 2009b). In the mycorrhizal symbiosis, JA were shown to accumulate (Hause et al. 2002; Isayenkov et al. 2005; López-Ráez et al. 2010; Stumpe et al. 2005); hence, a role for JA in restricting mycorrhizal colonization via the onset of a defense program was proposed (Gutjahr and Paszkowski 2009; Hause et al. 2007; López-Ráez et al. 2010). Similarly, the PGPF Piriformospora indica was shown to upregulate JA biosynthetic genes in the roots (Schafer et al. 2009), suggesting that activation of the JA signaling pathway may be a widely used strategy that plants employ to control colonization by beneficial endophytic fungi.

ET also appears to have a crucial role in maintaining a delicate balance between host plants and microsymbionts. In Rhizobium symbiosis, the number of rhizobial infections within the nodulation zone is under regulation and only a small number of infection threads persist and colonize nodules. The ETinsensitive mutant sickle of Medicago spp. is defective in this level of regulation and is hyperinfected by its microsymbiont $S$. meliloti (Penmetsa and Cook 1997). Because arrested infections often display characteristics of a hypersensitive response (Vasse et al. 1993), it is possible that ET regulates the number of successful infections by signaling certain defense responses within the nodulation zone. Supportive of this hypothesis is
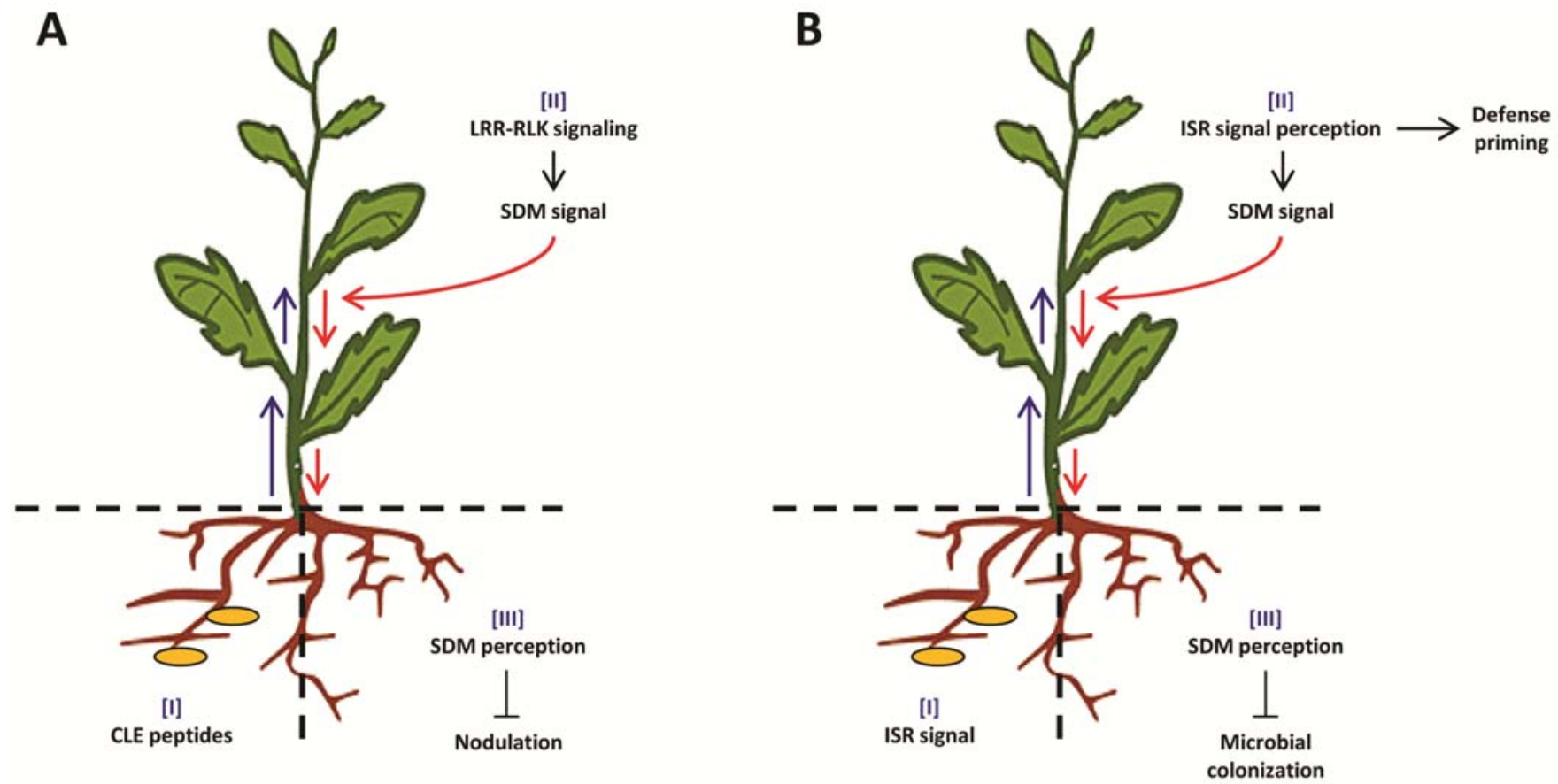

Fig. 4. Parallels between autoregulation of nodulation (AON) and induced systemic resistance (ISR). A, Proposed model for AON in the root nodule symbiosis in a split-root system (Oka-Kira and Kawaguchi 2006; Staehelin et al 2011). Clavata3/endosperm surrounding region (CLE) peptides are produced upon primary rhizobial infections and subsequently transported to the shoot, most likely through the xylem (stage I). Perception of CLE peptides in the shoot by the corresponding leucine-rich repeat receptor-like kinase (LRR-RLK) initiates a signaling cascade that results in the production of a phloem-mobile shoot-derived molecule (SDM) (stage II). SDM perception in the roots restricts nodulation (stage III). B, Proposed model for ISR in a split-root system. Root colonization by selected strains of plant-growth-promoting rhizobacteria (PGPR) results in the production of the ISR signal, which travels via the xylem to the aboveground tissues. Signal perception in the shoot may result in the production of a phloem-mobile SDM and priming for jasmonic acid/ethyleneregulated defense genes (stage II). SDM perception in the root results in enhanced resistance against root pathogens and, possibly, further restricts colonization by the beneficials (stage III). Blue and red arrows indicate movement via the xylem and phloem, respectively. 
that MtSkl1 mediates defense responses against a subset of Medicago pathogens (Varma Penmetsa et al. 2008). ET is also important in regulating the progress of root colonization by beneficial endophytic fungi. Camehl and associates (2010) recently demonstrated that overexpression of the ET-responsive transcription factor ERF1 in Arabidopsis resulted in reduced root colonization by the PGPF Piriformospora indica due to the potentiated activation of defense responses. Conversely, Piriformospora indica more effectively colonized roots of the ET-related mutants etr1, ein2, and ein3/eill (Camehl et al. 2010). Importantly, in both cases, the benefits for the host were diminished, indicating that ET homeostasis within the plant is crucial to control the extent of fungal colonization by regulating the expression of defense-related genes.

Systemic signaling in the control of beneficial interactions. By monitoring symbiont performance, leguminous plants are able to partly control the level of infection by Rhizobium spp. (e.g., through selective allocation of resources) (Kiers et al. 2003). In addition to these local responses, plants that establish a symbiosis with rhizobia can also control the number of infections and nodules through a systemic mechanism called autoregulation of nodulation (AON) (Oka-Kira and Kawaguchi 2006). AON is a two-step process and is mediated by longdistance signaling which involves both root- and shoot-derived signals (Fig. 4A). The root-derived signal is generated in response to primary rhizobial infections locally in the roots and is then translocated to the shoot. Upon perception, a second signal is generated and then translocated back to the root to activate a defense program that restricts further nodulation. A specific group of hypernodulating mutants defective in the shoot-regulated AON has been identified (Oka-Kira and Kawaguchi 2006). These mutants are all defective in homologs of CLAVATA1, an LRR receptor-like kinase involved in the regulation of shoot and floral meristem size of Arabidopsis. Recent work in M. truncatula and L. japonicus provided important evidence that Clavata3/endosperm surrounding region (CLE) peptides are candidate molecules for the root-derived signal (Mortier et al. 2010; Okamoto et al. 2009).

The AON phenomenon has striking mechanistic similarities to ISR and systemic acquired resistance (SAR) because, in all these cases, a microbial infection in local tissues leads to resistance against secondary infections in distant plant parts (Durrant and Dong 2004; Van Wees et al. 2008; Vlot et al. 2009). A possible connection between AON and defense signaling is supported by the fact that several autoregulation mutants are hypersusceptible to nematode and pathogen infection (Lohar and Bird 2003; Tazawa et al. 2007). In line with this, Kinkema and Gresshoff (2008) reported that, in soybean, a subset of defenserelated genes is regulated via the AON receptor GmNARK, albeit in a nodulation-independent manner. Interestingly, the CLAVATA3 peptide of Arabidopsis was recently reported to be capable of triggering immune signaling via the flagellin receptor (Lee et al. 2011), raising the possibility that CLE peptides may also be perceived in systemic tissues independent of the $\mathrm{AON}$ receptor kinase to trigger an immune response. Elicitation of induced resistance in the aboveground tissues was shown to impact beneficial plant-microbe interactions in the rhizosphere (de Roman et al. 2011; Faessel et al. 2010), which strengthens the notion that systemic defense signaling may be an intrinsic part of the AON phenomenon and functions in balancing the costs and benefits of the mutualistic relationship.

ISR: the resultant of an autoregulation signaling pathway?

Split-root experiments with AON mutants of soybean revealed that autoregulation in the rhizobial and mycorrhizal symbiosis is controlled in a similar manner (Meixner et al. 2005; Staehelin et al. 2011). Also, in the interaction with
PGPR, there is evidence that plants utilize systemic autoregulation mechanisms to control the beneficial interaction. For instance, in split-root experiments, it was shown that colonization of one-half of the roots by beneficial PGPR leads to enhanced defenses in the other part of the root system, which should have been mediated via a systemic signal (Leeman et al. 1996; Siddiqui and Shaukat 2002). Often, these systemically activated defenses are also expressed in aboveground plant tissues, giving rise to an ISR that is typically effective against a broad spectrum of plant pathogens and even insect herbivores (Pineda et al. 2010; Van Loon et al. 1998; Van Wees et al. 2008). In contrast to pathogen-induced SAR, which is dependent upon SA signaling and associated with enhanced expression of a large set of $P R$ genes (Durrant and Dong 2004; Vlot et al. 2009), PGPR- and PGPF-triggered ISR is often SAindependent and not associated with major changes in defenserelated gene expression (Van der Ent et al. 2009b). Instead, a relatively mild systemic immune reaction is triggered that is associated with priming for enhanced defense (Pozo et al. 2008; Van der Ent et al. 2008, 2009a). PGPR-primed plants do not express costly defenses but display an accelerated, often JA-dependent defense response upon pathogen or insect attack (Pozo et al. 2008; Stein et al. 2008; Van Hulten et al. 2006). Because priming only gives rise to activation of defense upon recognition of a potential intruder, it is an ideal mechanism to control the delicate interaction with invading beneficial microbes. Therefore, it is tempting to speculate that, in analogy to rhizobia and mycorrhizal symbiosis, beneficial associations with nonsymbiotic microbes are controlled by an autoregulation strategy of which the result is the ISR phenomenon that provides systemic protection in roots and shoots against a broad spectrum of pathogens (Fig. 4B).

\section{Concluding remarks.}

The boundaries between mutualism and pathogenesis are fluid. A nice example of this was recently demonstrated for the pathogenic bacterium Ralstonia solanacearum. Inactivation of the master virulence regulator $H r p G$ of this pathogen, which controls the expression of TTSS components and associated effectors, with concomitant transfer of the symbiotic plasmid of the microsymbiont Cupriavidus taiwanensis, was sufficient to shift the pathogen's behavior from pathogenic toward mutualistic (Marchetti et al. 2010). Moreover, the recent findings that mycorrhizal fungi employ effector-like molecules to manipulate the host's immune response (Kloppholz et al. 2011; Plett et al. 2011) and that host $R$ genes control specificity in the Rhizobium symbiosis (Yang et al. 2010) indicate that mutualistic and pathogenic interactions involve strikingly similar principles.

To date, research on plant responses to pathogenic and beneficial microbes has been largely separated. Due to the numerous commonalities in mechanisms and principles of both types of plant-microbe interactions, scientists from both fields have started to join forces to foster an integrated view of the molecular mechanisms that evolved in pathogenic and mutualistic plant-microbe interactions. Effector biology, which currently is a major topic in plant-pathogen interaction research, is becoming an active area in the field of beneficial plant-microbe interactions as well, and is anticipated to significantly improve our understanding of how mutualistic associations develop. With this review, we aimed to provide an overview of the mechanisms involved in the modulation of host immunity by symbiotic and nonsymbiotic beneficial microbes. We tried to identify commonalities between plant responses to different symbiotic beneficial and nonsymbiotic PGPR and generate an integrated view of how modulation of local and systemic defense responses aid in establishing the delicate balance between 
the two partners. Ultimately, research on the interplay between plants and beneficial microbes will provide detailed insight into how plants are able to shape the microbiome in their rhizosphere in order to maximize the profitable functions of their "second genome" (Mendes et al. 2011).

\section{ACKNOWLEDGMENTS}

This work was financially supported by the Greek State Scholarship Foundation, VICI grant number 865.04.002 of the Earth and Life Sciences Foundation, which is subsidized by the Netherlands Organization of Scientific Research, and ERC Advanced Grant number 269072 of the European Research Council. We apologize to those researchers whose work we were unable to discuss because of space limitations.

\section{LITERATURE CITED}

Achouak, W., Conrod, S., Cohen, V., and Heulin, T. 2004. Phenotypic variation of Pseudomonas brassicacearum as a plant root-colonization strategy. Mol. Plant-Microbe Interact. 17:872-879.

Albus, U., Baier, R., Holst, O., Puhler, A., and Niehaus, K. 2001. Suppression of an elicitor-induced oxidative burst reaction in Medicago sativa cell cultures by Sinorhizobium meliloti lipopolysaccharides. New Phytol. 151:597-606

Aslam, S. N., Newman, M. A., Erbs, G., Morrissey, K. L., Chinchilla, D., Boller, T., Jensen, T. T., De Castro, C., Ierano, T., Molinaro, A., Jackson, R. W., Knight, M. R., and Cooper, R. M. 2008. Bacterial polysaccharides suppress induced innate immunity by calcium chelation. Curr. Biol. 18:1078-1083.

Badri, D. V., and Vivanco, J. M. 2009. Regulation and function of root exudates. Plant Cell Environ. 32:666-681.

Bais, H. P., Park, S. W., Weir, T. L., Callaway, R. M., and Vivanco, J. M. 2004. How plants communicate using the underground information superhighway. Trends Plant Sci. 9:26-32.

Bakker, P. A. H. M., Pieterse, C. M. J., and Van Loon, L. C. 2007. Induced systemic resistance by fluorescent Pseudomonas spp. Phytopathology 97:239-243.

Bardoel, B. W., Van der Ent, S., Pel, M. J. C., Tommassen, J., Pieterse, C. M. J., Van Kessel, K. P. M., and Van Strijp, J. A. G. 2011. Pseudomonas evades immune recognition of flagellin in both mammals and plants. PLoS Pathog. 7:e1002206.

Bartsev, A. V., Deakin, W. J., Boukli, N. M., McAlvin, C. B., Stacey, G., Malnoe, P., Broughton, W. J., and Staehelin, C. 2004. NopL, an effector protein of Rhizobium sp. NGR234, thwarts activation of plant defense reactions. Plant Physiol. 134:871-879.

Baxter, L., Tripathy, S., Ishaque, N., Boot, N., Cabral, A., Kemen, E., Thines, M., Ah-Fong, A., Anderson, R., Badejoko, W., Bittner-Eddy, P., Boore, J. L., Chibucos, M. C., Coates, M., Dehal, P., Delehaunty, K., Dong, S. M., Downton, P., Dumas, B., Fabro, G., Fronick, C., Fuerstenberg, S. I., Fulton, L., Gaulin, E., Govers, F., Hughes, L., Humphray, S., Jiang, R. H. Y., Judelson, H., Kamoun, S., Kyung, K., Meijer, H., Minx, P., Morris, P., Nelson, J., Phuntumart, V., Qutob, D., Rehmany, A., Rougon-Cardoso, A., Ryden, P., Torto-Alalibo, T., Studholme, D., Wang, Y. C., Win, J., Wood, J., Clifton, S. W., Rogers, J., Van den Ackerveken, G., Jones, J. D. G., McDowell, J. M., Beynon, J., and Tyler, B. M. 2010. Signatures of adaptation to obligate biotrophy in the Hyaloperonospora arabidopsidis genome. Science 330:15491551.

Bisseling, T., Dangl, J. L., and Schulze-Lefert, P. 2009. Next-generation communication. Science 324:691-691.

Blilou, I., Ocampo, J. A., and Garcia-Garrido, J. M. 1999. Resistance of pea roots to endomycorrhizal fungus or Rhizobium correlates with enhanced levels of endogenous salicylic acid. J. Exp. Bot. 50:16631668

Boller, T., and Felix, G. 2009. A renaissance of elicitors: Perception of microbe-associated molecular patterns and danger signals by patternrecognition receptors. Annu. Rev. Plant Biol. 60:379-406.

Bonfante, P., and Genre, A. 2010. Mechanisms underlying beneficial plant-fungus interactions in mycorrhizal symbiosis. Nat. Commun. $1: 48$.

Boutrot, F., Segonzac, C., Chang, K. N., Qiao, H., Ecker, J. R., Zipfel, C., and Rathjen, J. P. 2010. Direct transcriptional control of the Arabidopsis immune receptor FLS2 by the ethylene-dependent transcription factors EIN3 and EIL1. Proc. Natl. Acad. Sci. U.S.A. 107:14502-14507.

Buttner, D., and Bonas, U. 2003. Common infection strategies of plant and animal pathogenic bacteria. Curr. Opin. Plant Biol. 6:312-319.

Camehl, I., Sherameti, I., Venus, Y., Bethke, G., Varma, A., Lee, J., and Oelmuller, R. 2010. Ethylene signalling and ethylene-targeted transcrip- tion factors are required to balance beneficial and nonbeneficial traits in the symbiosis between the endophytic fungus Piriformospora indica and Arabidopsis thaliana. New Phytol. 185:1062-1073.

Clay, N. K., Adio, A. M., Denoux, C., Jander, G., and Ausubel, F. M. 2009. Glucosinolate metabolites required for an Arabidopsis innate immune response. Science 323:95-101.

Davidson, C. J., and Surette, M. G. 2008. Individuality in bacteria. Annu. Rev. Genet. 42:253-268.

Deakin, W. J., and Broughton, W. J. 2009. Symbiotic use of pathogenic strategies: Rhizobial protein secretion systems. Nat. Rev. Microbiol. 7:312-320.

de Roman, M., Fernandez, I., Wyatt, T., Sahrawy, M., Heil, M., and Pozo, M. J. 2011. Elicitation of foliar resistance mechanisms transiently impairs root association with arbuscular mycorrhizal fungi. J. Ecol. 99:36-45.

De Vleesschauwer, D., and Höfte, M. 2009. Rhizobacteria-induced systemic resistance. Pages 223-281 in: Plant Innate Immunity. L. C. Van Loon, ed. Academic Press Ltd., Elsevier Science Ltd., London.

Dong, X. 2004. NPR1, all things considered. Curr. Opin. Plant Biol. 7:547-552.

Doornbos, R. F., Geraats, B. P. J., Kuramae, E. E., Van Loon, L. C., and Bakker, P. A. H. M. 2011. Effects of jasmonic acid, ethylene, and salicylic acid signaling on the rhizosphere bacterial community of Arabidopsis thaliana. Mol. Plant-Microbe Interact. 24:395-407.

Duijff, B. J., Gianinazzi-Pearson, V., and Lemanceau, P. 1997. Involvement of the outer membrane lipopolysaccharides in the endophytic colonization of tomato roots by biocontrol Pseudomonas fluorescens strain WCS417r. New Phytol. 135:325-334.

Durrant, W. E., and Dong, X. 2004. Systemic acquired resistance. Annu. Rev. Phytopathol. 42:185-209.

El Yahyaoui, F., Kuster, H., Ben Amor, B., Hohnjec, N., Puhler, A. Becker, A., Gouzy, J., Vernie, T., Gough, C., Niebel, A., Godiard, L., and Gamas, P. 2004. Expression profiling in Medicago truncatula identifies more than 750 genes differentially expressed during nodulation, including many potential regulators of the symbiotic program. Plant Physiol. 136:3159-3176.

Faessel, L., Nassr, N., Lebeau, T., and Walter, B. 2010. Chemically induced resistance on soybean inhibits nodulation and mycorrhization. Plant Soil 329:259-268.

Felix, G., Duran, J. D., Volko, S., and Boller, T. 1999. Plants have a sensitive perception system for the most conserved domain of bacterial flagellin. Plant J. 18:265-276

Glick, B. R., Cheng, Z., Czarny, J., and Duan, J. 2007. Promotion of plant growth by ACC deaminase-producing soil bacteria. Eur. J. Plant Pathol. 119:329-339.

Gutjahr, C., and Paszkowski, U. 2009. Weights in the balance: Jasmonic acid and salicylic acid signaling in root-biotroph interactions. Mol. Plant-Microbe Interact. 22:763-772.

Hallet, B. 2001. Playing Dr. Jekyll and Mr. Hyde: Combined mechanisms of phase variation in bacteria. Curr. Opin. Microbiol. 4:570-581

Harman, G. E., Howell, C. R., Viterbo, A., Chet, I., and Lorito, M. 2004 Trichoderma species-opportunistic, avirulent plant symbionts. Nat. Rev. Microbiol. 2:43-56.

Harrison, M. J. 2005. Signaling in the arbuscular mycorrhizal symbiosis. Annu. Rev. Microbiol. 59:19-42.

Hause, B., Maier, W., Miersch, O., Kramell, R., and Strack, D. 2002. Induction of jasmonate biosynthesis in arbuscular mycorrhizal barley roots. Plant Physiol. 130:1213-1220.

Hause, B., Mrosk, C., Isayenkov, S., and Strack, D. 2007. Jasmonates in arbuscular mycorrhizal interactions. Phytochemistry 68:101-110.

Heller, G., Adomas, A., Li, G. S., Osborne, J., van Zyl, L., Sederoff, R. Finlay, R. D., Stenlid, J., and Asiegbu, F. O. 2008. Transcriptional analysis of Pinus sylvestris roots challenged with the ectomycorrhizal fungus Laccaria bicolor. BMC Plant Biol. 8.

Isayenkov, S., Mrosk, C., Stenzel, I., Strack, D., and Hause, B. 2005. Suppression of allene oxide cyclase in hairy roots of Medicago truncatula reduces jasmonate levels and the degree of mycorrhization with Glomus intraradices. Plant Physiol. 139:1401-1410.

Jackson, R. W., Preston, G. M., and Rainey, P. B. 2005. Genetic characterization of Pseudomonas fluorescens SBW25 rsp gene expression in the phytosphere and in vitro. J. Bacteriol. 187:8477-8488.

Jacobs, S., Zechmann, B., Molitor, A., Trujillo, M., Petutschnig, E., Likpa, V., Kogel, K. H., and Schafer, P. 2011. Broad-spectrum suppression of innate immunity is required for colonization of Arabidopsis roots by the fungus Piriformospora indica. Plant Physiol. 156:726-740.

Jones, J. D. G., and Dangl, J. L. 2006. The plant immune system. Nature 444:323-329

Jones, K. M., Sharopova, N., Lohar, D. P., Zhang, J. Q., VandenBosch, K. A., and Walker, G. C. 2008. Differential response of the plant Medicago truncatula to its symbiont Sinorhizobium meliloti or an exopolysaccharide-deficient mutant. Proc. Natl. Acad. Sci. U.S.A. 105:704-709. 
Kamper, J., Kahmann, R., Bolker, M., Ma, L.J., Brefort, T., Saville, B. J., Banuett, F., Kronstad, J. W., Gold, S. E., Muller, O., Perlin, M. H., Wosten, H. A. B., de Vries, R., Ruiz-Herrera, J., Reynaga-Pena, C. G., Snetselaar, K., McCann, M., Perez-Martin, J., Feldbrugge, M., Basse, C. W., Steinberg, G., Ibeas, J. I., Holloman, W., Guzman, P., Farman, M., Stajich, J. E., Sentandreu, R., Gonzalez-Prieto, J. M., Kennell, J. C., Molina, L., Schirawski, J., Mendoza-Mendoza, A., Greilinger, D., Munch, K., Rossel, N., Scherer, M., Vranes, M., Ladendorf, O., Vincon, V., Fuchs, U., Sandrock, B., Meng, S., Ho, E. C. H., Cahill, M. J., Boyce, K. J., Klose, J., Klosterman, S. J., Deelstra, H. J., OrtizCastellanos, L., Li, W. X., Sanchez-Alonso, P., Schreier, P. H., HauserHahn, I., Vaupel, M., Koopmann, E., Friedrich, G., Voss, H., Schluter, T., Margolis, J., Platt, D., Swimmer, C., Gnirke, A., Chen, F., Vysotskaia, V., Mannhaupt, G., Guldener, U., Munsterkotter, M., Haase, D., Oesterheld, M., Mewes, H. W., Mauceli, E. W., DeCaprio, D., Wade, C. M., Butler, J., Young, S., Jaffe, D. B., Calvo, S., Nusbaum, C., Galagan, J., and Birren, B. W. 2006. Insights from the genome of the biotrophic fungal plant pathogen Ustilago maydis. Nature 444:97-101.

Kapulnik, Y., Volpin, H., Itzhaki, H., Ganon, D., Galili, S., David, R., Shaul, O., Elad, Y., Chet, I., and Okon, Y. 1996. Suppression of defence responses in mycorrhizal alfalfa and tobacco roots. New Phytol. 133:59-64.

Kazan, K., and Manners, J. M. 2009. Linking development to defense: Auxin in plant-pathogen interactions. Trends Plant Sci. 14:373-382.

Kiers, E. T., Rousseau, R. A., West, S. A., and Denison, R. F. 2003. Host sanctions and the legume-rhizobium mutualism. Nature 425:78-81

Kingsley, R. A., and Baumler, A. J. 2000. Host adaptation and the emergence of infectious disease: The Salmonella paradigm. Mol. Microbiol. 36:1006-1014.

Kinkema, M., and Gresshoff, P. M. 2008. Investigation of downstream signals of the soybean autoregulation of nodulation receptor kinase GmNARK. Mol. Plant-Microbe Interact. 21:1337-1348.

Kloepper, J. W., Ryu, C.-M., and Zhang, S. A. 2004. Induced systemic resistance and promotion of plant growth by Bacillus spp. Phytopathology 94:1259-1266.

Kloppholz, S., Kuhn, H., and Requena, N. 2011. A secreted fungal effector of Glomus intraradices promotes symbiotic biotrophy. Curr. Biol. 21:1204-1209.

Kniskern, J. M., Traw, M. B., and Bergelson, J. 2007. Salicylic acid and jasmonic acid signaling defense pathways reduce natural bacterial diversity on Arabidopsis thaliana. Mol. Plant-Microbe Interact. 20:15121522.

Kouchi, H., Shimomura, K., Hata, S., Hirota, A., Wu, G. J., Kumagai, H., Tajima, S., Suganuma, N., Suzuki, A., Aoki, T., Hayashi, M., Yokoyama, T., Ohyama, T., Asamizu, E., Kuwata, C., Shibata, D., and Tabata, S. 2004. Large-scale analysis of gene expression profiles during early stages of root nodule formation in a model legume, Lotus japonicus. DNA Res. 11:263-274.

Lee, H., Chah, O. K., and Sheen, J. 2011. Stem-cell-triggered immunity through CLV3p-FLS2 signalling. Nature 473:376-379.

Leeman, M., denOuden, E. M., vanPelt, J. A., Dirkx, F. P. M., Steijl, H., Bakker, P., and Schippers, B. 1996. Iron availability affects induction of systemic resistance to Fusarium wilt of radish by Pseudomonas fluorescens. Phytopathology 86:149-155.

Leon-Reyes, A., Spoel, S. H., De Lange, E. S., Abe, H., Kobayashi, M., Tsuda, S., Millenaar, F. F., Welschen, R. A. M., Ritsema, T., and Pieterse, C. M. J. 2009. Ethylene modulates the role of NONEXPRESSOR OF PATHOGENESIS-RELATED GENES1 in cross talk between salicylate and jasmonate signaling. Plant Physiol. 149:1797-1809.

Liu, J. Y., Blaylock, L. A., Endre, G., Cho, J., Town, C. D., VandenBosch, K. A., and Harrison, M. J. 2003. Transcript profiling coupled with spatial expression analyses reveals genes involved in distinct developmental stages of an arbuscular mycorrhizal symbiosis. Plant Cell 15:21062123.

Lohar, D. P., and Bird, D. M. 2003. Lotus japonicus: A new model to study root-parasitic nematodes. Plant Cell Physiol. 44:1176-1184.

Lohar, D. P., Sharopova, N., Endre, G., Penuela, S., Samac, D., Town, C., Silverstein, K. A. T., and VandenBosch, K. A. 2006. Transcript analysis of early nodulation events in Medicago truncatula. Plant Physiol. 140:221-234.

Lopez-Gomez, M., Sandal, N., Stougaard, J., and Boller, T. 2011. Interplay of flg22-induced defence responses and nodulation in Lotus japonicus. J. Exp. Bot. Online publication. doi:10.1093/jxb/err1291

López-Ráez, J. A., Verhage, A., Fernández, I., García, J. M., Azcón-Aguilar, C., Flors, V., and Pozo, M. J. 2010. Hormonal and transcriptional profiles highlight common and differential host responses to arbuscular mycorrhizal fungi and the regulation of the oxylipin pathway. J. Exp. Bot. 61:2589-2601.

Lugtenberg, B., and Kamilova, F. 2009. Plant-growth-promoting rhizobacteria. Annu. Rev. Microbiol. 63:541-556.
Maillet, F., Poinsot, V., Andre, O., Puech-Pages, V., Haouy, A., Gueunier, M., Cromer, L., Giraudet, D., Formey, D., Niebel, A., Martinez, E. A., Driguez, H., Becard, G., and Denarie, J. 2011. Fungal lipochitooligosaccharide symbiotic signals in arbuscular mycorrhiza. Nature 469:58U1501.

Marchetti, M., Capela, D., Glew, M., Cruveiller, S., Chane-Woon-Ming, B., Gris, C., Timmers, T., Poinsot, V., Gilbert, L. B., Heeb, P., Médigue, C., Batut, J., and Masson-Boivin, C. 2010. Experimental evolution of a plant pathogen into a legume symbiont. PLoS Biol. 8:e1000280.

Marie, C., Broughton, W. J., and Deakin, W. J. 2001. Rhizobium type III secretion systems: Legume charmers or alarmers? Curr. Opin. Plant Biol. 4:336-342.

Martin, F., Aerts, A., Ahren, D., Brun, A., Danchin, E. G. J., Duchaussoy, F., Gibon, J., Kohler, A., Lindquist, E., Pereda, V., Salamov, A., Shapiro, H J., Wuyts, J., Blaudez, D., Buee, M., Brokstein, P., Canback, B., Cohen, D., Courty, P. E., Coutinho, P. M., Delaruelle, C., Detter, J. C., Deveau, A., DiFazio, S., Duplessis, S., Fraissinet-Tachet, L., Lucic, E., Frey-Klett, P., Fourrey, C., Feussner, I., Gay, G., Grimwood, J., Hoegger, P. J., Jain, P., Kilaru, S., Labbe, J., Lin, Y. C., Legue, V., Le Tacon, F., Marmeisse, R., Melayah, D., Montanini, B., Muratet, M., Nehls, U., Niculita-Hirzel, H., Secq, M. P. O.-L., Peter, M., Quesneville, H., Rajashekar, B., Reich, M., Rouhier, N., Schmutz, J., Yin, T., Chalot, M., Henrissat, B., Kues, U., Lucas, S., Van de Peer, Y., Podila, G. K., Polle, A., Pukkila, P. J., Richardson, P. M., Rouze, P., Sanders, I. R., Stajich, J. E., Tunlid, A., Tuskan, G., and Grigoriev, I. V. 2008. The genome of Laccaria bicolor provides insights into mycorrhizal symbiosis. Nature 452:88-92.

Martin, F., Kohler, A., Murat, C., Balestrini, R., Coutinho, P. M., Jaillon, O., Montanini, B., Morin, E., Noel, B., Percudani, R., Porcel, B., Rubini, A., Amicucci, A., Amselem, J., Anthouard, V., Arcioni, S., Artiguenave, F., Aury, J. M., Ballario, P., Bolchi, A., Brenna, A., Brun, A., Buee, M., Cantarel, B., Chevalier, G., Couloux, A., Da Silva, C., Denoeud, F., Duplessis, S., Ghignone, S., Hilselberger, B., Iotti, M., Marcais, B., Mello, A., Miranda, M., Pacioni, G., Quesneville, H., Riccioni, C., Ruotolo, R., Splivallo, R., Stocchi, V., Tisserant, E., Viscomi, A. R., Zambonelli, A., Zampieri, E., Henrissat, B., Lebrun, M. H., Paolocci, F., Bonfante, P., Ottonello, S., and Wincker, P. 2010. Périgord black truffle genome uncovers evolutionary origins and mechanisms of symbiosis. Nature 464:1033-1038.

Martinez-Abarca, F., Herrera-Cervera, J. A., Bueno, P., Sanjuan, J., Bisseling, T., and Olivares, J. 1998. Involvement of salicylic acid in the establishment of the Rhizobium meliloti-Alfalfa symbiosis. Mol. PlantMicrobe Interact. 11:153-155.

Maunoury, N., Redondo-Nieto, M., Bourcy, M., Van de Velde, W., Alunni, B., Laporte, P., Durand, P., Agier, N., Marisa, L., Vaubert, D., Delacroix H., Duc, G., Ratet, P., Aggerbeck, L., Kondorosi, E., and Mergaert, P. 2010. Differentiation of symbiotic cells and endosymbionts in Medicago truncatula nodulation are coupled to two transcriptome-switches. PLoS One 5:e9519.

Mavrodi, D. V., Joe, A., Mavrodi, O. V., Hassan, K. A., Weller, D. M., Paulsen, I. T., Loper, J. E., Alfano, J. R., and Thomashow, L. S. 2011. Structural and functional analysis of the type III secretion system from Pseudomonas fluorescens Q8r1-96. J. Bacteriol. 193:177-189.

Mazurier, S., Lemunier, M., Siblot, S., Mougel, C., and Lemanceau, P. 2004. Distribution and diversity of type III secretion system-like genes in saprophytic and phytopathogenic fluorescent pseudomonads. FEMS (Fed. Eur. Microbiol. Soc.) Microbiol. Ecol. 49:455-467.

McCann, H. C., and Guttman, D. S. 2008. Evolution of the type III secretion system and its effectors in plant-microbe interactions. New Phytol. 177:33-47.

Medina, M. J. H., Gagnon, H., Piche, Y., Ocampo, J. A., Garrido, J. M. G. and Vierheilig, H. 2003. Root colonization by arbuscular mycorrhizal fungi is affected by the salicylic acid content of the plant. Plant Sci. 164:993-998.

Meixner, C., Ludwig-Muller, J., Miersch, O., Gresshoff, P., Staehelin, C., and Vierheilig, H. 2005. Lack of mycorrhizal autoregulation and phytohormonal changes in the supernodulating soybean mutant nts1007. Planta 222:709-715.

Mendes, R., Kruijt, M., De Bruijn, I., Dekkers, E., Van der Voort, M., Schneider, J. H. M., Piceno, Y. M., DeSantis, T. Z., Andersen, G. L., Bakker, P. A. H. M., and Raaijmakers, J. M. 2011. Deciphering the rhizosphere microbiome for disease-suppressive bacteria. Science 332:1097-1100

Mersmann, S., Bourdais, G., Rietz, S., and Robatzek, S. 2010. Ethylene signaling regulates accumulation of the FLS2 receptor and Is required for the oxidative burst contributing to plant immunity. Plant Physiol. 154:391-400

Millet, Y. A., Danna, C. H., Clay, N. K., Songnuan, W., Simon, M. D., Werck-Reichhart, D., and Ausubel, F. M. 2010. Innate immune responses activated in Arabidopsis roots by microbe-associated molecular patterns. Plant Cell 22:973-990. 
Mitra, R. M., and Long, S. R. 2004. Plant and bacterial symbiotic mutants define three transcriptionally distinct stages in the development of the Medicago truncatula/Sinorhizobium meliloti symbiosis. Plant Physiol. 134:595-604.

Moreau, S., Verdenaud, M., Ott, T., Letort, S., de Billy, F., Niebel, A., Gouzy, J., de Carvalho-Niebel, F., and Gamas, P. 2011. Transcription reprogramming during root nodule development in Medicago truncatula. PLoS One 6:e16463.

Mortier, V., Den Herder, G., Whitford, R., Van de Velde, W., Rombauts, S., D'Haeseleer, K., Holsters, M., and Goormachtig, S. 2010. CLE peptides control Medicago truncatula nodulation locally and systemically. Plant Physiol. 153:222-237.

Niehaus, K., Kapp, D., and Puhler, A. 1993. Plant defence and delayed infection of alfalfa pseudonodules induced by an exopolysaccharide (EPS I)-deficient Rhizobium meliloti mutant Planta 190:415-425.

Oka-Kira, E., and Kawaguchi, M. 2006. Long-distance signaling to control root nodule number. Curr. Opin. Plant Biol. 9:496-502.

Okamoto, S., Ohnishi, E., Sato, S., Takahashi, H., Nakazono, M., Tabata, S., and Kawaguchi, M. 2009. Nod factor/nitrate-induced CLE genes that drive HAR1-mediated systemic regulation of nodulation. Plant Cell Physiol. 50:67-77.

Oldroyd, G. E. D., and Downie, J. M. 2008. Coordinating nodule morphogenesis with rhizobial infection in legumes. Annu. Rev. Plant Biol. 59:519-546

Oldroyd, G. E. D., Harrison, M. J., and Paszkowski, U. 2009. Reprogramming plant cells for endosymbiosis. Science 324:753-754.

Paszkowski, U. 2006. Mutualism and parasitism: The yin and yang of plant symbioses. Curr. Opin. Plant Biol. 9:364-370.

Peleg-Grossman, S., Golani, Y., Kaye, Y., Melamed-Book, N., and Levine, A. 2009. NPR1 protein regulates pathogenic and symbiotic interactions between Rhizobium and legumes and non-legumes. PLoS One 4:e8399.

Penmetsa, R. V., and Cook, D. R. 1997. A legume ethylene-insensitive mutant hyperinfected by its rhizobial symbiont. Science 275:527-530.

Pieterse, C. M. J., Leon-Reyes, A., Van der Ent, S., and Van Wees, S. C. M. 2009. Networking by small-molecule hormones in plant immunity. Nat. Chem. Biol. 5:308-316.

Pineda, A., Zheng, S.-J., Van Loon, J. J. A., Pieterse, C. M. J., and Dicke, M. 2010. Helping plants to deal with insects: The role of beneficial soilborne microbes. Trends Plant Sci. 15:507-514.

Plett, J. M., Kemppainen, M., Kale, S. D., Kohler, A., Legue, V., Brun, A., Tyler, B. M., Pardo, A. G., and Martin, F. 2011. A secreted effector protein of Laccaria bicolor is required for symbiosis development. Curr. Biol. 21:1197-1203.

Pozo, M. J., and Azcon-Aguilar, C. 2007. Unraveling mycorrhiza-induced resistance. Curr. Opin. Plant Biol. 10:393-398.

Pozo, M. J., Van der Ent, S., Van Loon, L. C., and Pieterse, C. M. J. 2008. Transcription factor MYC2 is involved in priming for enhanced defense during rhizobacteria-induced systemic resistance in Arabidopsis thaliana. New Phytol. 180:511-523.

Preston, G. M., Bertrand, N., and Rainey, P. B. 2001. Type III secretion in plant growth-promoting Pseudomonas fluorescens SBW25. Mol. Microbiol. 41:999-1014.

Rainey, P. B. 1999. Adaptation of Pseudomonas fluorescens to the plant rhizosphere. Environ. Microbiol. 1:243-257.

Rezzonico, F., Defago, G., and Moenne-Loccoz, Y. 2004. Comparison of ATPase-encoding type III secretion system $h r c N$ genes in biocontrol fluorescent Pseudomonads and in phytopathogenic proteobacteria. Appl. Environ. Microbiol. 70:5119-5131.

Sanchez, L., Weidmann, S., Arnould, C., Bernard, A. R., Gianinazzi, S. and Gianinazzi-Pearson, V. 2005. Pseudomonas fluorescens and Glomus mosseae trigger DMI3-dependent activation of genes related to a signal transduction pathway in roots of Medicago truncatula. Plant Physiol. 139:1065-1077.

Schafer, P., Pfiffi, S., Voll, L.M., Zajic, D., Chandler, P. M., Waller, F., Scholz, U., Pons-Kuhnemann, J., Sonnewald, S., Sonnewald, U., and Kogel, K. H. 2009. Manipulation of plant innate immunity and gibberellin as factor of compatibility in the mutualistic association of barley roots with Piriformospora indica. Plant J. 59:461-474.

Schechter, L. M., Guenther, J., Olcay, E. A., Jang, S. C., and Krishnan, H. B. 2010. Translocation of NopP by Sinorhizobium fredii USDA257 into Vigna unguiculata root nodules. Appl. Environ. Microbiol. 76:37583761

Scheidle, H., Gross, A., and Niehaus, K. 2005. The Lipid A substructure of the Sinorhizobium meliloti lipopolysaccharides is sufficient to suppress the oxidative burst in host plants. New Phytol. 165:559-565.

Shoresh, M., Harman, G. E., and Mastouri, F. 2010. Induced systemic resistance and plant responses to fungal biocontrol agents. Annu. Rev. Phytopathol. 48:21-43.

Siciliano, V., Genre, A., Balestrini, R., Cappellazzo, G., deWit, P., and Bonfante, P. 2007. Transcriptome analysis of arbuscular mycorrhizal roots during development of the prepenetration apparatus. Plant Physiol. 144:1455-1466.

Siddiqui, I. A., and Shaukat, S. S. 2002. Rhizobacteria-mediated induction of systemic resistance (ISR) in tomato against Meloidogyne javanica. J. Phytopathol. 150:469-473.

Sirrenberg, A., Goebel, C., Grond, S., Czempinski, N., Ratzinger, A. Karlovsky, P., Santos, P., Feussner, I., and Pawlowski, K. 2007. Piriformospora indica affects plant growth by auxin production. Physiol. Plant. 131:581-589.

Spaink, H. P. 2000. Root nodulation and infection factors produced by rhizobial bacteria. Annu. Rev. Microbiol. 54:257-288.

Stacey, G., McAlvin, C. B., Kim, S. Y., Olivares, J., and Soto, M. J. 2006. Effects of endogenous salicylic acid on nodulation in the model legumes Lotus japonicus and Medicago truncatula. Plant Physiol. 141:14731481.

Staehelin, C., Xie, Z. P., Illana, A., and Vierheilig, H. 2011. Long-distance transport of signals during symbiosis: Are nodule formation and mycorrhization autoregulated in a similar way? Plant Signal. Behav. 6:372377.

Stein, E., Molitor, A., Kogel, K. H., and Waller, F. 2008. Systemic resistance in Arabidopsis conferred by the mycorrhizal fungus Piriformospora indica requires jasmonic acid signaling and the cytoplasmic function of NPR1. Plant Cell Physiol. 49:1747-1751.

Stumpe, M., Carsjens, J. G., Stenzel, I., Gobel, C., Lang, I., Pawlowski, K., Hause, B., and Feussner, I. 2005. Lipid metabolism in arbuscular mycorrhizal roots of Medicago truncatula. Phytochemistry 66:781791.

Tazawa, J., Takahashi, M., Usuki, K., and Yamamoto, H. 2007. Nodulation during vegetative growth of soybean stage does not affect the susceptibility to red crown rot caused by Calonectria ilicicola. J. Gen. Plant Pathol. 73:180-184

Tellstrom, V., Usadel, B., Thimm, O., Stitt, M., Kuster, H., and Niehaus, K. 2007. The lipopolysaccharide of Sinorhizobium meliloti suppresses defense-associated gene expression in cell cultures of the host plant Medicago truncatula. Plant Physiol. 143:825-837.

Ton, J., Pieterse, C. M. J., and Van Loon, L. C. 1999. Identification of a locus in Arabidopsis controlling both the expression of rhizobacteriamediated induced systemic resistance (ISR) and basal resistance against Pseudomonas syringae pv. tomato. Mol. Plant-Microbe Interact. 12:911-918.

Ton, J., Van Pelt, J. A., Van Loon, L. C., and Pieterse, C. M. J. 2002. The Arabidopsis ISRI locus is required for rhizobacteria-mediated induced systemic resistance against different pathogens. Plant Biol. 4:224-227.

Van den Broek, D., Bloemberg, G. V., and Lugtenberg, B. 2005. The role of phenotypic variation in rhizosphere Pseudomonas bacteria. Environ. Microbiol. 7:1686-1697.

Van der Ent, S., Verhagen, B. W. M., Van Doorn, R., Bakker, D., Verlaan, M. G., Pel, M. J. C., Joosten, R. G., Proveniers, M. C. G., Van Loon, L. C., Ton, J., and Pieterse, C. M. J. 2008. MYB72 is required in early signaling steps of rhizobacteria-induced systemic resistance in Arabidopsis. Plant Physiol. 146:1293-1304.

Van der Ent, S., Van Hulten, M. H. A., Pozo, M. J., Czechowski, T. Udvardi, M. K., Pieterse, C. M. J., and Ton, J. 2009a. Priming of plant innate immunity by rhizobacteria and B-aminobutyric acid: Differences and similarities in regulation. New Phytol. 183:419-431.

Van der Ent, S., Van Wees, S. C. M., and Pieterse, C. M. J. 2009b. Jasmonate signaling in plant interactions with resistance-inducing beneficial microbes. Phytochemistry 70:1581-1588.

Van der Heijden, M. G. A., Klironomos, J. N., Ursic, M., Moutoglis, P., Streitwolf-Engel, R., Boller, T., Wiemken, A., and Sanders, I. R. 1998. Mycorrhizal fungal diversity determines plant biodiversity, ecosystem variability and productivity. Nature 396:69-72.

Van der Woude, M. W., and Baumler, A. J. 2004. Phase and antigenic variation in bacteria. Clin. Microbiol. Rev. 17:581-611.

Van Hulten, M., Pelser, M., Van Loon, L. C., Pieterse, C. M. J., and Ton, J. 2006. Costs and benefits of priming for defense in Arabidopsis. Proc. Natl. Acad. Sci. U.S.A. 103:5602-5607.

Van Loon, L. C., Bakker, P. A. H. M., and Pieterse, C. M. J. 1998. Systemic resistance induced by rhizosphere bacteria. Annu. Rev. Phytopathol. 36:453-483

Van Loon, L. C., Bakker, P. A. H. M., Van der Heijdt, W. H. W., Wendehenne, D., and Pugin, A. 2008. Early responses of tobacco suspension cells to rhizobacterial elicitors of induced systemic resistance. Mol. Plant-Microbe Interact. 21:1609-1621.

Van Spronsen, P. C., Tak, T., Rood, A. M. M., van Brussel, A. A. N., Kijne, J. W., and Boot, K. J. M. 2003. Salicylic acid inhibits indeterminatetype nodulation but not determinate-type nodulation. Mol. PlantMicrobe Interact. 16:83-91.

Van Wees, S. C. M., Pieterse, C. M. J., Trijssenaar, A., Van't Westende, Y. A. M., Hartog, F., and Van Loon, L. C. 1997. Differential induction of 
systemic resistance in Arabidopsis by biocontrol bacteria. Mol. PlantMicrobe Interact. 10:716-724.

Van Wees, S. C. M., Van der Ent, S., and Pieterse, C. M. J. 2008. Plant immune responses triggered by beneficial microbes. Curr. Opin. Plant Biol. 11:443-448.

Varma Penmetsa, R., Uribe, P., Anderson, J., Lichtenzveig, J., Gish, J.-C., Nam, Y. W., Engstrom, E., Xu, K., Sckisel, G., Pereira, M., Baek, J. M., Lopez-Meyer, M., Long, S. R., Harrison, M. J., Singh, K. B., Kiss, G. B., and Cook, D. R. 2008. The Medicago truncatula ortholog of Arabidopsis EIN2, sickle, is a negative regulator of symbiotic and pathogenic microbial associations. Plant J. 55:580-595.

Vasse, J., Debilly, F., and Truchet, G. 1993. Abortion of infection during the Rhizobium meliloti-alfalfa symbiotic interaction is accompanied by a hypersensitive reaction. Plant J. 4:555-566.

Verhage, A., van Wees, S. C. M., and Pieterse, C. M. J. 2010. Plant immunity: It's the hormones talking, but what do they say? Plant Physiol. 154:536-540.

Verhagen, B. W. M., Glazebrook, J., Zhu, T., Chang, H. S., van Loon, L. C., and Pieterse, C. M. J. 2004. The transcriptome of rhizobacteriainduced systemic resistance in Arabidopsis. Mol. Plant-Microbe Interact. 17:895-908

Vlot, A. C., Dempsey, D. A., and Klessig, D. F. 2009. Salicylic acid, a multifaceted hormone to combat disease. Annu. Rev. Phytopathol. 47:177-206
Wang, Y. Q., Ohara, Y., Nakayashiki, H., Tosa, Y., and Mayama, S. 2005. Microarray analysis of the gene expression profile induced by the endophytic plant growth-promoting rhizobacteria, Pseudomonas fluorescens FPT9601-T5 in Arabidopsis 18:385-396.

Wasternack, C. 2007. Jasmonates: An update on biosynthesis, signal transduction and action in plant stress response, growth and development. Ann. Bot. 100:681-697.

Wenzel, M., Friedrich, L., Gottfert, M., and Zehner, S. 2010. The type III-secreted protein NopE1 affects symbiosis and exhibits a calciumdependent autocleavage activity. Mol. Plant-Microbe Interact. 23:124129.

Wisniewski-Dye, F., and Vial, L. 2008. Phase and antigenic variation mediated by genome modifications. Anton. Leeuw. Int. J. G. 94:493-515

Yang, F.-J., Cheng, L.-L., Zhang, L., Dai, W.-J., Liu, Z., Yao, N., Xie, Z.P., and Staehelin, C. 2009. Y4IO of Rhizobium sp. strain NGR234 is a symbiotic determinant required for symbiosome differentiation. J. Bacteriol. 191:735-746.

Yang, S., Tang, F., Gao, M. Q., Krishnan, H. B., and Zhu, H. Y. 2010. $R$ gene-controlled host specificity in the legume-rhizobia symbiosis. Proc. Natl. Acad. Sci. U.S.A. 107:18735-18740.

Zeidler, D., Zahringer, U., Gerber, I., Dubery, I., Hartung, T., Bors, W., Hutzler, P., and Durner, J. 2004. Innate immunity in Arabidopsis thaliana: Lippopolysaccharides activate nitric oxide synthase (NOS) and induce defense genes. Proc. Natl. Acad. Sci. U.S.A. 101:15811-15816. 